\title{
Legal Forest Management Problems: EU Experience
}

\author{
Anna Liubchych ${ }^{1}$, Olena Savchuk ${ }^{2}$, Kateryna Vrublevska-Misiuna ${ }^{3}$
}

\begin{abstract}
The work contains the analysis of forestry management legal problems in Ukraine and the European Union, highlighting the problematic points in the national legislation and the possibility of implementing the experience of developed countries.

There are singled out the ways to improve forestry legislation, with accentuating the need in developing a nation-wide forestry program which would regulate forestry management with accounting for preservation of the forest's ecology function and biologic potential. It is proved that a woodcutting site has attributes of a forestry relations object as a plot of the forest fund of Ukraine with established borders.

Also, there arises the need in revising the Regulation on territorial offices of the central executive power body that carries out state policies in forestry and in bringing it to the correspondence with the requirements of standing legislation of Ukraine and the Regulation on State forest inspection of Ukraine, granting it plenary powers similar to those in the leading European countries, for instance "forest guard" of the Republic of Poland.
\end{abstract}

Key words: Forest; Woodcutting; Timber harvesting; Forest resources; Woodcutting site; Forestry management; Forest site; Forestry.

\section{Introduction}

Woodlands comprise 15.9 per cent of the territory of Ukraine. The forests on the state's territory are distributed unevenly, covering from 3.7 per cent in Zaporizhia to 51.4 per cent in Zakarpattia (Trans Carpathian) oblasts (areas). In accordance with European recommendations, the optimal one is the woodland indicator of 20 per cent, to attain which will require creating of more than two million hectares of new forests. At the same time, creating of new forests should not be carried out through forestation of unique steppe areas.

The main reason for arising problems in the forestry sphere is imperfection of the forestry management and development system, the absence of legal and economic mechanisms to stimulate the introduction of nature sparing technologies, imperfect taxation base, as well as a diffused definition of the legal status concerning land management of field-protection wood-belts areas.

\footnotetext{
| 1 Scientific Secretary of Institute, scientific associate, Scientific and Research Institute of Providing Legal Framework for the Innovative Development National Academy of Law Sciences of Ukraine, ORCID:https://orcid.org/0000-0002-6492-4179.

${ }^{2} \mathrm{PhD}$ is scientific associate, Scientific and Research Institute of Providing Legal Framework for the Innovative Development National Academy of Law Sciences of Ukraine, ORCID: https://orcid.org/0000-0003-3299-7936.

${ }^{3} \mathrm{PhD}$ senior lecturer, O. M. Beketov National University of Urban Economy in Kharkiv, ORCID: https://orcid.org/0000-0002-6973-3945.
} 
Coordination of works related to woods protection and restoring are maintained by the central (in state-owned forests) and local executive power bodies (in the communal-owned forests). Around 0.8 million hectares of state-owned woodlands (including field-protection wood-belts) are not allotted for economy use and are referred to the reserve lands. An unclear definition of the legal status concerning land management of field protection wood-belts leads to considerable deterioration of green plantations' state and to their destruction.

The absence of forestry activities financing system, especially in the eastern and southern regions of Ukraine, has led to termination of works on creating protective wood-belts on low-yield and degraded lands and to the failure to perform preventive fire protection measures in the forests, which has raised the risk of arising forest fires, appearing of breeding grounds for pests and forest illnesses, to forests' drying out and deterioration of ecology situation ${ }^{1}$.

\section{The study of procedural problems in the legislation of Ukraine}

According to the norms of parts 3, 4 Art. 51 of the Law of Ukraine "On Environment Protection" of 25.01.1991 No. 1264-XII (in the edition of 12.10.2018), economic and other activities projects are to contain materials on estimating the activity's influence on the environment and people's health. The estimation is conducted with taking into account the requirements of environment protection legislation, the territory's ecologic capacity, the state of environment in the place of potential construction of objects, ecologic prognoses, perspectives of the region's socio-economic development, intensity and kinds of the integrated impact of harmful factors and objects on the environment.

The plenary powers concerning organization of estimating the impact on the environment by industrial and other objects, as well as by chemical substances on forests are stipulated by the Art. 29, 29-1 of the Forestry Code of Ukraine (hereinafter the FC of Ukraine).

The Law of Ukraine of 23.05.2017 No.2059-VIII “On Estimating the Impact on the Environment" enacted on the 18.12.2018 establishes the legal and organizational foundations of evaluating the environmental impact directed at avoiding damage to the environment, ensuring ecologic safety, environment protection, rational use and restoring of natural resources in the course of taking decisions concerning economic activities that can cause an impact on the environment with taking into account the state, public, and private interests.

In para. 2 and sub-para. 21 Art. 3 of the mentioned Law, it is determined that to the first category of perspective activities and objects that can cause a considerable impact on the environment and are subject to estimation of the environmental impact pertain all clear cuttings for business use and clear sanitary cuttings on areas exceeding 1 hectare.

\footnotetext{
1 On the Fundamental Principles (Strategy) of the State Environmental Policy of Ukraine for the Period up
} to 2030. The Verkhovna Rada Bulletin, 2019, no 16, p. 70. (in Ukraine) 
It should be noted that clear and gradual wood cuttings are related to industry-related cutting, the legal regime of which is determined by the FC of Ukraine, the Cabinet of Ministers of Ukraine Decree of 23.05.2007 No, 761 "On Regulating the Issues Concerning Special Use of Forest Resources", and the order of the State Forestry Agency of Ukraine of 23.12.2009 No. 364, which approves the "Rules of Industrial Woodcutting" (registered in the Ministry of Justice of Ukraine on 26.02.2010 No. $85 / 17380)$.

The plenary powers concerning organization of estimating the impact on the environment by industrial and other objects, as well as by chemical substances on forests are stipulated by the Art. 29, 29-1 of the Forestry Code of Ukraine (hereinafter the FC of Ukraine).

The Law of Ukraine of 23.05.2017 No.2059-VIII "On Estimating the Impact on the Environment" enacted on the 18.12 .2018 establishes the legal and organizational foundations of evaluating the environmental impact directed at avoiding damage to the environment, ensuring ecologic safety, environment protection, rational use and restoring of natural resources in the course of taking decisions concerning economic activities that can cause an impact on the environment with taking into account the state, public, and private interests.

In para. 2 and sub-para. 21 Art. 3 of the mentioned Law, it is determined that to the first category of perspective activities and objects that can cause a considerable impact on the environment and are subject to estimation of the environmental impact pertain all clear cuttings for business use and clear sanitary cuttings on areas exceeding 1 hectare.

It should be noted that clear and gradual wood cuttings are related to industryrelated cutting, the legal regime of which is determined by the FC of Ukraine, the Cabinet of Ministers of Ukraine Decree of 23.05.2007 No, 761 "On Regulating the Issues Concerning Special Use of Forest Resources", and the order of the State Forestry Agency of Ukraine of 23.12.2009 No. 364, which approves the "Rules of Industrial Woodcutting" (registered in the Ministry of Justice of Ukraine on 26.02.2010 No. $85 / 17380)$.

Requirements to the conducting of sanitary woodcutting are stipulated by the FC of Ukraine, the decrees by the Cabinet of Ministers of Ukraine of 12.05.2007 No. 724 “On Approval of the Rules of Forests' Qualitative Composition Improvement", of 27.07.1995 No. 555 (in the edition of the Decree of the Cabinet of Ministers of Ukraine of 26.10.2016 No. 756) "On Approval of Sanitary Rules in the Forests of Ukraine", and other normative-legal acts. Observing the requirements of the "Sanitary Rules in the Forests of Ukraine" is directed at taking measures on improvement of forests' sanitary state, as well as requirements set forth in order to protect forests in the course of maintaining forestry management, utilizing forest resources, and conducting forestry works not connected with forestry management by enterprises, offices, organizations, and citizens. According to the mentioned rules, the following measures are taken to improve the sanitary state of forests: selective sanitary woodcutting, clear sanitary cutting; elimination of cluttering-up, prevention of the appearing and spreading of pests' breeding sites and forest illnesses, fighting them, and protection of harvested wood from pests and forest illnesses. Clear woodcutting is referred to measures of forests' sanitary state improvement and are performed by forests owners or permanent forest users in 
order to normalize plantations in shortest periods of time on conditions of avoiding a negative impact on the environment. These measures are part of a complex of preventive measures that are taken in order to maintain the plantations' stability, avoid the development of pathology processes in a forest, minimize the damage caused by pests and illnesses, and eliminate the effects of accidents or natural disasters.

Wood harvesting in the course of industrial wood cutting and cutting connected with forestry management is conducted by forests' owners and permanent forest users who are granted this right in due course (Art. 37 of the FC of Ukraine). The term "woodcutting" is defined in the normative State Standard (DSTU) 3404-96 "FORESTRY. Terms and definitions" as cutting and removing trees from a forest. The issues concerning industrial woodcutting, improvement of forests' qualitative composition are regulated by normative-legal acts pertaining to forestry management (Art. 37 of the FC of Ukraine), mentioned above.

Wood harvesting is conducted in the course of utilizing forest resources in the form of industrial woodcuttings that are made in ripe and overdue woods. For industrial woodcutting first of all are allotted the damaged trees, those suffering from drying out, other woods that demand urgent cutting due to their state, as well as the woods that have terminated their juice supply cycle. Depending on the category of forests, natural forestplant conditions, biologic peculiarities of wood species, and other peculiarities of wood sites, the following industrial cutting systems are applied: clear, gradual or selective, combinative cuttings. Wood is also harvested during forestry management measures not connected with forest resources utilizing (improvement of forests' qualitative composition), and during other measures (clearing forested sites allotted for the construction of hydro-systems, pipelines, roads, etc.).

According to Art 2 of the FC of Ukraine, forestry relations are social relations concerning ownership, utilizing, and controlling the forests and are directed at ensuring protection, restoring, and steady utilizing of forest resources with taking into account economic, social, and other interest of society. The object of forestry relations is the forest fund of Ukraine and separate forest sites.

To the forest fund of Ukraine pertain forest sites including protective plantations of linear type with an area exceeding 0.1 hectare. To the forest fund of Ukraine do not pertain: green plantations within populated areas (parks, public gardens, boulevards, etc.) that are not referred in due order to forests; separate trees and detached groups of trees, bushes on agricultural lands, household, country-cottage, and garden plots of land (para. 4 Art. 1 of the FC of Ukraine).

A forest site is a section of the forest fund of Ukraine with established limits, allotted in accordance with the FC $\mathrm{f}$ Ukraine for conducting forestry business and utilizing forest resources without alienating it from the land user or the land owner (para 4 Art. 1 of the FC of Ukraine).

To forestry lands pertain forested lands, on which forest sites are located, as well as non-forested lands under agricultural fields, bodies of water and marshes, buildings, communications, as well as low-yielding lands allotted in due order and being utilized for the needs of forestry business (Art. 5 of the LC of Ukraine). According to Art. 55 of the Land Code of Ukraine, to forestry lands pertain the lands covered in forest plants, and non-forested lands that are allotted and being used for the needs of forestry business. 
Land use organization ensures access to information on the amount and quality of lands, their condition, and other data needed for the state land cadaster, land monitoring, and exercising state control of lands' utilizing and protection (Art. 2 of the Law of Ukraine "On Land Management").

According to the "Procedures for Keeping State Forest Cadaster and Forests Account" (approved by the Cabinet of Ministers of Ukraine decree of 20.06.2007 No. 848), the cadaster documentation is kept on the basis of the state land cadaster data, forestry management materials, inventories, surveying and initial account of forests separately for individual forest owners or forest users on the grounds of documents determined in Art. 52 of the FC of Ukraine.

In the course of referring the forests to corresponding categories, the forest sites limits for each category are established. Referring a forest site to a specific system, kind, and way of cutting, determining organization and technical elements in accordance with these Rules are fulfilled during conducting forestry-managing works with taking into account local conditions (para 2.9 of the "Industrial Woodcutting Rules" approved by the State Forest Agency of Ukraine order of 23.12.2009 No. 364). A forest site limit is a conventional closed broken line on the surface of land for separation of forest sites. The borderlines of forest sites selected for referring to one of the categories are drawn along natural boundaries, block cuttings, communication and electricity lines, and other borderlines clearly discernable on the site (Art. 40 of the FC of Ukraine). The standing legislation also states that other borderlines clearly discernable on the site can serve as borderlines of forest sites' designated for referring to one of the categories as well, namely: railways and roads, ditches, gas and oil pipelines, geodesic marks, fire protection gaps, and watershed lines (the Cabinet of Ministers of Ukraine Decree of 16.05.2007 No. 733 “On approval of the Procedures of Forests' Classification into Categories and Allotting Specially Protected Forest Sites").

According to the "Methodology of determining forests territories as pertaining to primeval forests, quasi-virgin forests, and natural forests" (approved by the Ministry of Energy and Nature Protection order of 18.05.2018 No. 161, registered at the Ministry of Justice on 11.06.2018 No. 707/32159), at the preliminary stage are selected those forest sites that potentially correspond to the criteria of determining forests territories as pertaining to primeval forests, quasi-virgin forests, and natural forests as stated in the Appendix 1 of this Methodology and are to be further surveyed in situ on the basis of data of forestry management materials, the results of science literature analysis, archive and other materials, information obtained from forestry workers, communities, and individual citizens.

Wood harvesting is one of the types of special utilizing of forests, the procedures and conditions of the said special utilizing of forests being established by the Cabinet of Ministers of Ukraine (para 4, Art. 67 of the FC of Ukraine). Wood harvesting is carried out in the course of forest resources' utilizing in the form of industrial cutting and during performing measures not connected with forest resources' utilizing like improvement of forests' qualitative composition (paras. 1 and 4, Art. 70 of the FC of Ukraine). During fulfilling forests formation and improvement cuttings, sanitary cuttings are used among other measures (para. 2 of the "Rules of Forests' Qualitative Composition 
Improvement"). Clear sanitation cuttings are conducted to improve forests' sanitary state (para.4 of the "Sanitary Rules in the Forests of Ukraine").

It should also be borne in mind that special utilizing of forest resources is conducted within the boundaries of forest sites allotted for this purpose (para. 3 Art. 67 of the FC of Ukraine). Special utilizing of forest resources is carried out on forest sites allotted for this purpose without granting the plots of land. A forest site can be allotted to one or several temporary forest users for various kinds of forest resources utilizing (paras. 1-2, Art. 68 of the FC of Ukraine). Notably, the wood procured in the course of carrying out the measures on clearing forest sites covered with forest trees for construction hydrographic objects, pipelines, roads, and so on, is considered a taxation object and special rent payment is to be charged for special utilizing of forest resources (Art. 256 of the Tax Code of Ukraine).

According to para. 36 of the "Special Utilizing of Forest Resources Regulations" approved by the Cabinet of Ministers of Ukraine Decree of 23.05.2007 No. 761, allotment of forest sites for wood harvesting in the course of industrial cutting is carried out by woodcutting areas allotment and taxation subunits whose composition is approved by forest owners or permanent users with confirmation on behalf of the State forest agency bodies. Thus, in connection with wood harvesting in the course of conducting wood cutting the term "wood-cutting area" is used.

It should be noted that the FC of Ukraine does not provide a definition of the aforementioned notion, so in order to clarify its meaning it is necessary to turn to other normative-legal acts, for according to Art. 3 of the FC of Ukraine, forestry relations in Ukraine are regulated by the Constitution of Ukraine, the Law of Ukraine "On Natural Environment Protection", the Forestry Code, and other legislative acts of Ukraine along with other normative-legal acts adopted in accordance with them.

According to Art. 25 of the FC of Ukraine, state regulating and management in the forestry relations sphere is carried out as follows:

1) forming and determining the main directions of state policies in the forestry relations sphere;

2) determining the plenary powers of executive power bodies and local authority bodies by law;

3) establishing in accordance with law the procedure and regulations in the sphere of forests safeguarding, protection, utilizing, and restoring;

4) administering state supervision over the forests safe-guarding, protection, utilizing, and restoring.

Along with this, the articles 26-33 of the FC of Ukraine delineate the circle of state agencies that administer state regulating and management in the forestry relations sphere, including their plenary powers. Among these governing bodies, a special place is given to State Agency of Forest Resources of Ukraine (Derzhlis agency), which was established as a result of re-organizing of the State Forestry Committee of Ukraine (Derzhcomlisgosp of Ukraine) on the grounds of the Edict of the President of Ukraine "On Optimizing the System of Central Executive Power Bodies" of 09.12.2010 No. 1085/2010. In its 
activities, the Derzhlis agency is governed by the Regulation on the State Agency of Forest Resources of Ukraine approved by the Cabinet of Ministers of Ukraine Decree of 08.10.2014 No. 521.

This attests to the effect, that prior 09.12.2010, the state regulating and management in the forestry relations sphere were administered by the Derzhcomlisgosp (State Forestry Committee) of Ukraine, among other things through approving by-laws concerning forestry management.

According to the Regulation on the State Agency of Forest Resources of Ukraine, which was approved by the President of Ukraine's Edict of 14.08.2000 No. 969/2000, the State Forestry Committee of Ukraine was the central executive power body, whose activities were directed and coordinated by the Cabinet of Ministers of Ukraine (para.1, part 1). The Derzhcomlisgosp of Ukraine was vested, among other things, in authority to set forth in the established order the propositions concerning the formation of state policy in the sphere of forestry and hunting, ensuring its enactment, administering management in this field, as well as inter-branch coordination and functional regulation of issues related to its administration (para.1, part 2).

Notably, through issuing by-laws, legal specification takes place. The goal of such specification is to enhance the precision and the unambiguity of legal regulation to attain which is necessary to make a certain contextual reformulation of a norm in the course of specification, which will make the norm's content more precise. At the same time, the specifying acts should (and must) serve in themselves as a foundation for solving specific legal cases, that is they can pose as independent and immediate regulators of social relations.

To this effect, it should be mentioned that lawyers single out several different approaches concerning the issue of in which activity sphere the specification of law is present and what it is per se. In particular, it may be the specification which: 1) is inherent to any process of law realization, it means detailing a norm to the maximum precision within a legal act or even a norm's transiting into a subject's individual behavior; 2) is a development, in connection with certain peculiar circumstances, of broader, specific regulations that do not reach the status of a legal norm; 3) acts as a kind of legal activity of power bodies; 4) comprises a genus notion that encompasses phenomena peculiar to both law-making and to law-application practices ${ }^{2}$.

Thus, guiding by para. 1 Art. 47 of the FC of Ukraine (in the edition valid prior 16.10.12) stating that "Forestry management is obligatory all over the territory of Ukraine and is carried out according to a single system and in the order established by the central executive power body on the forestry issues", the State Forestry Committee of Ukraine issued the "Instruction on Regulating Forest Fund of Ukraine" (part 1 Field works. Irpin' - 2006; hereinafter the 2006 Instruction), which was approved by the Science-and-Technical Council of Derzhcomlisgosp of Ukraine decision, protocol No. 2 of October 30 - November 1, 2006).

${ }^{2}$ Krasiuk I.A. Specification of law in ensuring a hierarchy of legal acts. Available at: http://www.apdp.in.ua/v70/19.pdf . (in Ukraine) 
An obligatory requirement set forth to any normative-legal act, along with the stipulation that it should be issued within the authority of the corresponding state power body, its strict precision, etc., is the requirement of its corresponding to the acts issued by supreme state bodies, that is the requirement of observing the hierarchy principle, due to which effect the uniformity of numerous acts (and norms) and their coordinated action are attained in legislation. It is also supposed that a state body authority boundaries concerning the issuing of such normative-legal acts cannot be interpreted indiscriminately or to broaden it up, they should be limited by the law in a clear and precise way. This forms the foundation of the hierarchy characteristic for normative acts as a source of right, any violation of authority boundaries of any state body leads to affecting the links, interdependencies, and wholesomeness of the sources of right system in general. Therefore, any normative-legal act has its own destination, goal, and tasks.

It follows from the aforementioned that the Dershcomlisgosp (State Forestry Committee) of Ukraine was vested in duties concerning forestry relations regulation by the President of Ukraine Edict No. 969/2000. Thus, the Dershcomlisgosp of Ukraine issued the 2006 Instruction in question in accordance and on the grounds of forestry legislation set forth in Art. 3 of the Forestry Code of Ukraine. This makes it possible to come to the conclusion that the 2006 Instruction can be considered as a specifying act that can (and must) pose an independent and immediate regulator of forestry relations. Currently, despite the corresponding organizations of the mentioned state agencies, the said 2006 Instruction has not been abolished by any normative-legal act, which means that it is still in force.

The 2006 Instruction states: forestry management by purpose designation falls into: initial, periodic recurrent and permanent, and special kinds of observation (subpara. 1.4.1.); the initial forestry management is carried out in the forests that are managed for the first time (sub-para. 1.4.1.1.); periodic recurrent forestry management is carried out in previously managed objects after the termination of the inventory period (subpara. 1.4.1.2.); at permanent forestry management, annual inventory is carried out only for that part of the forest fund, which was involved in economic activities or was considerably affected by natural phenomena or by adjoining new lands. As a result of undertaking forestry management measures, the forest fund characteristics are renewed yearly, current plans for cutting and other activities are drawn for specific sites, and control of their utilizing is administered (part 2, sub-para 1.4.1.3.).

A similar specifying character pertains to other normative documents concerning forestry relations regulation. It is possible to include to their number the corresponding standards as well, because Art. 15 of the Industrial Code of Ukraine states that in economic sphere technical regulations, standards, codes of traditional practices, and technical specifications are applied. It is notable, that in Ukraine there is no separate state standard of terms used in forestry management, but the meaning of these terms are supplied in special instructions. For instance, the basic document that contains detailed valuation characteristics of each allotment in the forest fund of a forestry is valuation description (sub-para 2.4. of the "Instructions on Forestry Management in the Forest Fund...". Part 2. Preliminary works. Book 1. Approved on 31.05 .1990 by the Derzhcomlis (State Forestry Committee) resolution No. 6). 
In particular, the term "woodcutting area" is defined in the DSTU (State Standard of Ukraine) 3404-96 "FORESTRY Terms and definitions" and should be understood as a forest site allotted for cutting the trees of special (main) utilizing, of maintaining, restoring, and sanitary cuttings, which is delimitated by boundary marks, pickets, marks, or natural borders.

To clarify, the State Standards of Ukraine (DSTU) are standards developed in accordance with the standing legislation of Ukraine. According to the Law of Ukraine "On Standardization" of 05.06.2014 No.1315-VII, a standard is a normative document based on consensus and approved by a recognized power body, which establishes for general and repetitive use the rues, instructions or characteristics concerning an activity or its outcomes, and aimed at attaining the corresponding optimal degree of order in certain sphere (part 1 para 20 Art 1). It should be noted that the application of the Law of Ukraine "On Standardization" extends to relations connected with activities both in the sphere of standardization and that of its results application. On the other hand, the application of this normative-legal act does not extend to sanitary measures of food products' safety, veterinary and phyto-sanitary measures, construction norms, medicines, medical help standards, accountancy, property evaluation, educational and other social standards provided for by legislation. The object of standardization is requirements to terminology (para 3, part 1, Art 53).

According to the Law of Ukraine "On Environment Protection", namely Art. 32, state standards in the natural environment protection sphere are binding and determine the notions and terms, the modes of natural resources' utilizing and protection, the methods of monitoring the state of the natural environment, requirements concerning avoiding pollution of the natural environment, other issues related to the natural environment protection and utilizing of natural resources; ecology standards are developed and enacted in the order determined by legislation of Ukraine.

We'd like to accentuate on state standards' in the natural environment protection sphere being binding. This means the need in coordinating forestry relations subjects' behavior with their legal duties. Among other things, their implementation is guaranteed through a possibility of applying state compulsion measures. In other words, such standards are binding for all the forestry relations subjects. Neither can they be binding in a greater or lesser extent, that is why it is incorrect to speak about a degree of obligation, so the standards are equally binding for any subject they extend on.

Besides, state standards in the natural environment protection sphere possess the same characteristic as normativity. Traditionally, there are distinguished several characteristics of normativity, namely: inprecision (depersonification) of an addressee, permanent character of their effect; as well as its lasting effect regardless of execution. Thus, the state standards are directed at regulating a kind of social relations, at establishing certain order binding for all.

Thus, a forest site as a forestry relations object is allotted for forest resources utilizing, one of types of which is special utilizing of forest resources, including wood harvesting by means of industrial cutting and clear sanitary cutting, which is conducted within the forest sites allotted for trees cutting, that is within woodcutting areas. In the case when a forest site is allotted for wood harvesting, including the undertaking of the mentioned cuttings, we speak about the territory of forestry land that is called a 
woodcutting area, that is a woodcutting area possesses characteristics of a forestry relations object as a section of the forest fund of Ukraine with delimitated borders.

\section{The EU experience for the forestry sphere of Ukraine}

Ukraine is currently at the stage of transition to the market economy system, including the forestry relations sphere. To fulfil this task, the European Union's experience will be beneficial, for the EU countries have positive experience in this area; nevertheless, our state's national peculiarities should also be taken into consideration. Moreover, Ukraine and the EU have signed the Association Agreement, which is a token of further development of relations between the parties, directed at economic integration. To fulfil the Association Agreement, there were approved a plan of measures on the Association Agreement implementation between Ukraine on the one side and the European Union on the other side for the period of $2014-2017$.

In Europe, unlike with agricultural policy, there is no common forestry policy. Nevertheless, due to the lack of a common legal act concerning the actions on the European Commission level, to harmonize all forestry policies in different EU countries, the European Commission developed in 2013 the Joint Strategy of Forestry Management. In the EU Forestry Strategy, there are determined the following specialization areas, to which the member counties agreed and voted their obligations: 1) stable conducting of business activity in the forest enhances attaining common social targets: support of rural and city areas; promoting competitiveness and stability of forestry business as well as bioenergy production and the EU green economy in general; forests in the ever changing climate; forest protection and improvement of ecosystems productivity; 2) development of fundamental knowledge of: what forests we have, and how do they change? New and innovative forestry products with a high added value; 3 ) enhancing cooperation and communication: more common work on coherent conducting of business activities and a better understanding of our forests; forests in global perspective ${ }^{3}$.

Thus, in Germany, for instance, according to its standing legislation, a forest is any area of soil with naturally growing or planted forest plants. As a forest, they also consider soil areas after clear woodcutting or thinning out, forest roads, forest-dividing lines, and protective plantations, forest clearings and glades, wood-pastures, game feeding places, wood stock keeping places, as well as other areas connected with forest or the ones that serve its needs. Some federal lands have specified this definition and broadened it as needed, but have not narrowed it. Nevertheless, there is no such notion in a narrow sense common to different federal lands, because the issues of the trees' density (wood stock per hectare) are regulated differently (or are not regulated at all). This means that the question, if an area of soil is planted with / covered in forest plants densely enough to be referred to as forest in the sense of the Forest Law, is answered by different lands in a different way ${ }^{4}$.

${ }^{3}$ Zettser F. Basic forestry report in Germany with recommendations for Ukraine. Kiev, 2018, 36 p. (p. 16). (in Ukraine)

4 Zetzer F. Basic forestry report in Germany with recommendations for Ukraine. Kyiv, 2018, p. 11. (in Ukraine) 
In Germany, doing business in a federal land forest is clearly related to "Lands' forests" and is strictly separated institutionally and on the personnel scale from political influence. The "Lands' forests" are responsible for doing business in a forest belonging to a federal land within the scope of goals of economic activities prescribed by the ministry. Meanwhile, of setting political targets, the "Lands' forests" are notified by the parliament and the ministry. This means, that decisions on a specific business activity in the forest is taken by a single responsible institution, instead of many institutions.

One of the reasons of quite rare conflicts of targets in relation to forest areas is the fact that in each federal land the supervision on forestry enterprises of a federal land is administered by only one ministry, which means, that there is a clear and unanimous responsibility. This means, that every year the ministry assigns to a forestry enterprise of a federal land a clear operative goal, attaining of which is also annually checked in the yearly accounts on the state of matters, as well as through executing a control in person. There exists a rigorous reporting system wherein the "Lands' forests" have to report on goals attaining to the corresponding ministry. As for doing business, forestry enterprises of federal lands are free, but only to the extent of being able to achieve the set goal ${ }^{5}$.

In Germany, there acts a full-fledged national forest program, the main principles of which are: national sovereignty and responsibility in utilizing forest resources; partnership of all interested groups; a long-term process of planning, development, and control in the forestry branch. These principles are implemented under the state administration control, and the main instrument of forest policy is legal regulations: laws and (executive power's) decrees. The Federal Forest Law includes instructions and orders that have the restrictive function with sanctions provided for their violation. The main goals, fixed in the preamble to the law are correct doing forestry business for preservation of the forest's ecological functions and biologic potential. This point is very important, because it removes forest resources from the category of a commodity to that of a service ${ }^{6}$.

The federal law, the main issues of which are duplicated in the regional laws of lands, regulates the duties of all forest owners on the territories where cutting is made. Thus, private or communal forestry enterprises are to plant new forests in determined terms until natural forest reproduction is restored to a full extent. Apart from the frame law, there operate in the forestry sphere a number of legislative acts: On forest seeding; On forest losses and balances; On wood selling; On hunting on federal lands, and so on. Another important element of forest policies is institutional frames (limits), which in practice ensure legal agreements between market participants at all the level of branch control. According to the Federal law, a forestry and industry are the competency of federal lands. Each land has an administrative body that ensures the interests of forest owners, maintains the monitoring and consulting for the sector. In some federal lands, these functions are performed by corresponding agricultural administrations. The main state stakeholder at the federal level is the Federal Forestry Ministry of Germany. Its

\footnotetext{
${ }^{5}$ Zetzer F. p. 26. (in Ukraine)

${ }^{6}$ Economy. Online newspaper. More information: http://economica.com.ua (Last Accessed on 26.12.2019). (in Ukraine)
} 
plenary authority is not quite broad and comes down mostly to enhancing education and investments in forestry business. The Ministry determines the strategy of utilizing, protection, and restoring of the nation's forests and has a consultative function in relation to forest administrations at the federal lands level ${ }^{7}$.

In Italy, standing legislation obliges forestry enterprises to plan forestry business, but only half of public forests is covered by planning. The forest resources restoring planning is used as an instrument by means of which the state and the international donations are regulated; these donations are directed at the improvement of forests' state, forest road network development, etc. Taxing of forests is based on the forest cadaster. Forest owners pay taxes on profits from land, capital, and work. The taxes rates are varied depending on the profit level. Juridical persons pay income tax at the rate of $25 \%$. Besides, forest owners are charged with the local tax which is $15 \%$ of the profit. The income tax in Italy decreases when forests are located higher than 700 meters above sea level. In this way, they stimulate forestry business development in mountainous areas, which are characterized as by different nature- and economy conditions of forest resources concentration. In Italy, they have introduced special tax on goods produced from paper and paper pulp within $0.6-3.0 \%$ of the realization price. The accumulated funds are spent to support plant nurseries, on technical support and research work on plantation wood growing . $^{8}$

In Finland, the administrative organizations reporting to the Ministry of Agriculture and Forestry that develops forest policies and implement them in practices of doing forestry business are: 13 regional forestry centers, the Forestry Development Center Tapio, the Central Union of Agricultural Producers and Forest Owners, the Finnish Forest Association, the Finnish Forest Industries Federation, Finnish Environment Institute "SYKE", the Natural Resources Institute of Finland, the European Forest Institute. The National Forest Program-2015 contains the main directions of Finland's forest policies, and at the regional level, considering perspectives of each region's development, there have been developed regional forest programs. The principle of stable forestry development, which makes the foundation of the Law on the Forest, is comprised of the three equal relating to one another components that ensure steady forests' development: ecologic, social, and economic components. An important instrument of Finland's forestry policy is the tax system. In forestry business, apart from traditional kinds of taxes, special taxes are used, namely, the income tax on the sold wood (gross forestry income also includes the amount of forestry works made by the forest owner and his/her family members). In Finland, the state-owned forests are exempt from taxation?.

\footnotetext{
${ }^{7}$ Economy. Online newspaper. More information: http://economica.com.ua (Last Accessed on 26.12.2019). (in Ukraine)

${ }^{8}$ Lenio RV. Perspective directions of introduction of foreign experience in the forestry management system of Ukraine. Public administration: theory and practice. 2012, no 2, Access mode: http://nbuv.gov.ua/UJRN/Dutp_2012_2 21. (in Ukraine)

${ }^{9}$ Finnish forestry complex. More information: http://compi.com.ua/lisopromislovij-kompleksfinlyandsekoyi-respubliki.html_Last Accessed on 26.12.2019).
} 
The Finnish legislation also provisions for the state control of selling privately-owned forest lands. The control over forest lands sales is administered by corresponding associations. Without their permission, forest owners can sell forest sites the area of which does not exceed 2 hectares. Financing of keeping state bodies of forestry management is made on account of funds of the state budget and forest owners' payments (the money is deduced annually on the basis of special agreement). On account of state budget funds, direct financing of forestry activities can be made if they ensure a raise in forests' productivity. In 2014, as a result of far-reaching reforms, the legal base in the forestry sphere was renewed and supplemented: to the Law on forest there were added amendments to the section of private forests management, and raising forestry's profitability. The Law on Financing Forests' Steady Development will enhance a more efficient ecology management in private forests and utilizing of wood for energy production. There were introduced amends to the Law on Environment Protection and to the Law on Placing Wood and Forestry Products in the market. The legislation facilitates forming favorable conditions for forestry development, which is also an object of political support on behalf of the state. The state also provides financial assistance to long-term investments in forestry, among which are forest roads construction, renewal meliorating, forests planting, and use of wood as an energy source ${ }^{10}$.

\section{Conclusions and proposals}

In order to improve forest management in Ukraine and to ensure conducting of non-extensive utilizing of forests, as well as to eliminate illegal wood cutting, we think it necessary to take the following measures:

1) to develop a modern, oriented at the European experience (with taking into consideration the best national legacy in the forestry sphere), "Forests of Ukraine" national program for the period of 2020 - 2030, which would balance forestry business and preservation of the forest's ecology function and biologic potential;

2) to revise standing normative-legal acts that regulate forestry enterprises' activities and to bring them in correspondence with the standing legislation of Ukraine;

3) to develop new corresponding normative-legal acts (instructions, etc.), which are to regulate clearly and in detail all the facets of doing forestry business in Ukraine, first of all in forest management and wood cutting;

4) to bring the terminology in every law and by-laws that regulate forestry activities to the correspondence with the content of standing national standards;

5) to complement the national standards that regulate forestry activities with the corresponding necessary terms and definitions (that already exist in the national legislation) of the European Union;

6) to introduce changes to the national legislation that would make it impossible to interpret the same legal norm in more than one way, including the Law of Ukraine "On Estimation of the Environmental Impact";

${ }^{10}$ Finnish forestry complex. More information: http://compi.com.ua/lisopromislovij-kompleksfinlyandsekoyi-respubliki.html(Last Accessed on 26.12.2019). 
7) to revise the Regulation on Territorial Offices of the Central Executive Power Body that implements state policy in the forestry sphere and to bring it in correspondence with the requirements of standing legislation of Ukraine;

8) to revise the Regulation on the State Forest Protection Service of Ukraine, endowing it with authority like that in the leading European countries, for instance the "forest guard" of the Polish Republic;

9) to provide for the employees of the State Forest Protection Service at the lower level the modern technical means (including transportation), and to revise and modernize their service duties at all levels in order to prevent illegal wood cutting or to timely detect them along with the persons who committed them;

10) to establish responsibility under which forestry managers at all levels would be unable to employ for the positions in the State Forest Protection Service the persons with no specialized forestry education;

11) to grant for permanent use to acting state or communal forestry enterprises (or to create new ones) the forests belonging to former agricultural cooperatives, including field-protection belts, allotting to this effect necessary sums from the state budget;

12) at the Cabinet of Ministers of Ukraine level to set to the national forestry science the precise and urgent tasks concerning fulfilment of the state's European aspirations through developing the "Forests of Ukraine" national program for the period of 2020 2030 along with development of the legislative and normative-legal base for its successful implementation and to allot to this effect the needed sums.

\section{References:}

On the Fundamental Principles (Strategy) of the State Environmental Policy of Ukraine for the Period up to 2030. The Verkhovna Rada Bulletin. 2019, no 16., p. 70. (in Ukrainian)

Bratusia S.N., Samoshchenko Y.S.Theoretical issues of systematization of Soviet legislation. Moskov: Soiuryzdat Publ., 1962, p. 62-66. (in Russian)

Constitution of Ukraine. Official Bulletin of Ukraine. 1996, no 30, Art. 141. (in Ukrainian)

DSTU 3404-96 «FORESTRY. Terms and definitions. Access mode: http://gostsnip.su/document/dstu_340496_lisivnictvo_termini_ta_viznachennya (in Ukrainian)

Economy. Online newspaper. More information: http://economica.com.ua (Last Accessed on 26.12.2019). (in Ukraine)

Finnish forestry complex. More information: http://compi.com.ua/lisopromislovij-kompleksfinlyandsekoyi-respubliki.html (Last Accessed on 26.12.2019).

Forest Code of Ukraine. The Verkhovna Rada Bulletin. 1994, no 17, p. 99. (in Ukrainian)

Krasiuk I.A. Specification of law in ensuring a hierarchy of legal acts. Available at: http://www.apdp.in.ua/v70/19.pdf . (in Ukraine)

Law of Ukraine "On land management". The Verkhovna Rada Bulletin. 2003, no 36, Art. 282. (in Ukrainian)

Law of Ukraine "On standardization". dated 05.06.2014 №1315-VII. Official Bulletin of Ukraine. 2014, no 31. Art. 1058. (in Ukrainian)

Law of Ukraine "On the protection of the environment". Official Bulletin of Ukraine. 1991, no. 41, Art. 546. (in Ukrainian)

Law of Ukraine "On the protection of the environment". The Verkhovna Rada Bulletin. 1991, no 41, p 546. (in Ukrainian)

Law of Ukraine "On environmental impact assessment". The Verkhovna Rada Bulletin. 2017, no 29, p. 315. (in Ukrainian)

Lenio RV. Perspective directions of introduction of foreign experience in the forestry management system of Ukraine. Public administration: theory and practice. 2012, no 2, Access mode: http://nbuv.gov.ua/UJRN/Dutp_2012_2_21. (in Ukrainian) 
Methods of determining the belonging of forest areas to primeval forests, quasi-virgin forests and natural forests. By the order of the Ministry of Energy and Environmental Protection of May 18, 2018, no 161. Official Bulletin of Ukraine. 2018, no. 50, Art. 1769 (in Ukrainian)

On approval of the Order of division of forests into categories and selection of especially protective forest areas. Resolution of the Cabinet of Ministers of Ukraine of May 16, 2007, no. 733, Official Bulletin of Ukraine 2007, no. 37, Art. 1483. (in Ukrainian)

On approval of the Rules for improving the quality of forests. Resolution of the Cabinet of Ministers of Ukraine dated 12.05.2007, no. 724. Official Bulletin of Ukraine. 2007, no 37, Art. 1478. (in Ukrainian)

On approval of the Sanitary Rules in the forests of Ukraine. Cabinet of Ministers Resolution No. 555 of July 27, 1995. (in Ukrainian)

On the regulation of issues related to the special use of forest resources. Resolution of the Cabinet of Ministers of Ukraine of 23.05.2007, no 761. Official Bulletin of Ukraine. 2007, No. 39, Art. 1550. (in Ukrainian)

Regulation on the State Forest Resources Agency of Ukraine. Official Bulletin of Ukraine. 2014, no 82. Art. 2333. (in Ukrainian)

Rules for cutting down the main use. Order of the State Forestry Agency of Ukraine dated December 23, 2009. No. 364. Official Bulletin of Ukraine. 2010, no 6, Art. 276. (in Ukrainian)

Rules for improving the quality of forests. Decree of the Cabinet of Ministers of May 12, 2007. No. 724. Official Gazette of Ukraine. 2007, no. 37. Art. 1478. (in Ukrainian)

Tax Code of Ukraine. Official Bulletin of Ukraine. 2011, no 13-14, no 15-16, no 17, Art. 112. (in Ukrainian)

The procedure of maintaining the state forest cadastre and accounting of forests. Resolution of the Cabinet of Ministers of Ukraine dated 20.06.2007. No. 848. Official Bulletin of Ukraine. 2007, no 46, Art. 1885. (in Ukrainian)

Zetzer F. Basic forestry report in Germany with recommendations for Ukraine. Kyiv, 2018, 36 p. (in Ukrainian) 